\title{
Expression and roles of glutamate (NMDA) receptors on $T$ cell subsets
}

\author{
Kanami Orihara ${ }^{1 *}$, Solomon O Odemuyiwa ${ }^{2}$, Nyla Dil ${ }^{1}$, Vidyanand Anaparti ${ }^{1}$, Redwan Mogbel ${ }^{1}$ \\ From Canadian Society of Allergy and Clinical Immunology Annual Scientific Meeting 2010 \\ Victoria, Canada. 3-6 November 2010
}

\section{Rationale}

Tryptophan is an essential amino acid and its oxidative catabolism, through the action of its rate-limiting enzyme, indoleamine 2,3 dioxygenase (IDO), generates functional molecules in neurons. We studied the function of the tryptophan catabolism pathway on immune regulation. We have shown previously that human eosinophils constitutively express bioactive IDO and that co-culture of eosinophils with T-helper cells resulted in Th1-, but not Th2 apoptosis and inhibited proliferation. IDO-mediated tryptophan catabolism results in bioactive kynurenines (KYNs). Since KYNs exert their effect on neurons via glutamate-mediated cell death (excitotoxicity) that targets NMDA ( $N$-methyl- $D$-aspartate) glutamate receptors (NMDA-Rs), we examined NMDA-R phenotype and function in Th1 vs. Th2 immune regulation.

\section{Materials and methods}

Naïve CD4 T cells were separated from PBMCs and differentiated to Th1 and Th2 using established methods. Expression of NMDA-Rs was detected using reverse transcript PCR, real-time PCR, Western blotting and flow cytometry. $\mathrm{T}$ cell proliferation and apoptosis was detected by CSFE- and Annexin V-staining, respectively. We measured $\mathrm{Ca}^{2+}$ flux by Fluo-3 and Fura Red.

\section{Results}

We determined the presence of RNA and protein expression of metabolic glutamate receptors on all T-helper cell subtypes using 7 NMDA-R documented subtypes. Apoptotic and anti-proliferative effects of KYNs were exerted on Th1, but not Th2, as was KYN-

\footnotetext{
* Correspondence: oriharak@cc.umanitoba.ca

${ }^{1}$ Department of Immunology, Faculty of Medicine, University of Manitoba, Winnipeg, MB, Canada, R3E OT5

Full list of author information is available at the end of the article
}

induced $\mathrm{Ca}^{2+}$ flux. These effects were significantly inhibited with the specific NMDA-R competitive inhibitor, MK-801.

\section{Conclusion}

These findings suggest that NMDA-Rs on T cells may play an important role in promoting Th2 polarization in allergies and reduction of Th1 cell resulting in Th2 bias in allergy.

\section{Author details}

'Department of Immunology, Faculty of Medicine, University of Manitoba, Winnipeg, MB, Canada, R3E 0T5. '2Pulmonary Research Group, University of Alberta, Edmonton, AB, Canada, T6G 2S2.

Published: 4 November 2010

doi:10.1186/1710-1492-6-S2-P24

Cite this article as: Orihara et al:: Expression and roles of glutamate

(NMDA) receptors on T cell subsets. Allergy, Asthma \& Clinical Immunology 2010 6(Suppl 2):P24.

Submit your next manuscript to BioMed Central and take full advantage of:

- Convenient online submission

- Thorough peer review

- No space constraints or color figure charges

- Immediate publication on acceptance

- Inclusion in PubMed, CAS, Scopus and Google Scholar

- Research which is freely available for redistribution 